\title{
An assessment of the nutritive value of a maize-soya mixture, 'Soy-Ogi', as a weaning food in Nigeria
}

\author{
By I. A. AKINRELE AND CHARITY C. A. EDWARDS \\ Federal Institute of Industrial Research, \\ P.M.B. I023, Ikeja, Lagos, Nigeria
}

(Received 4 August 1970-Accepted 12 March 1971)

\begin{abstract}
r. Sour maize pap fortified with soya (Soy-Ogi), developed at the Federal Institute of Industrial Research, Oshodi, Nigeria has been evaluated chemically for its nutrient composition, biologically for protein quality and toxicity, and therapeutically on patients with kwashiorkor.

2. The indications are that it is a complete protein food suitable for feeding to children after weaning, and it compares favourably and economically with milk foods.

3. It was successfully used to restore normal health to children suffering from kwashiorkor.
\end{abstract}

Kwashiorkor, a protein-deficiency syndrome, is a major debilitating disease of children in many developing countries. This is due largely to the low purchasing power of the majority of the population which denies them access to adequate weaning foods. In Nigeria, for example, Morley (1958) observed that one out of every five children brought into the Wesley Guild Hospital, Ilesha (population I65822) was in this condition, and he was seeing up to 300 cases of kwashiorkor in 1 year (Collis, Dema \& Omololu, 1962). Brock (196I) went further to suggest that for every one case of kwashiorkor there were 100 cases of protein malnutrition in the pre-kwashiorkor condition. The traditional weaning food used in this locality and by over Io million Yorubas living in the Western States of Nigeria is a maize preparation called 'ogi' (pap). Williams (1933) first reported the incidence of kwashiorkor among children between the ages of $I$ and 4 years in the Gold Coast, now known as Ghana. In all the cases examined there was a history of deficient breast-feeding, and the only supplementary food used was a similar preparation of maize called 'akasa'.

The traditional method of preparation of ogi consists of soaking maize grains in cold water for $1-3 \mathrm{~d}$, then wet-milling them with fresh water and sieving the slurry through a screen mesh of about British sieve size no. 36 . The liquor is finally left to stand for another day or two at room temperature (about $30^{\circ}$ ), when it sediments and turns sour. The wet cake is usually boiled in water to give a gruel containing about $5 \%$ solids and used in this form for feeding infants. Akinrele (I966) found that the biological quality of the protein of ogi is so poor that it does not support growth in rats, but, when it is supplemented with heated full-fat soya in the proportions of 70 parts of ogi to 30 parts of soya, the protein efficiency ratio (PER) increases threefold, making the protein almost as good as casein. With the aim of bringing relief to Nigerian children in particular, the Federal Institute of Industrial Research has developed a process for the incorporation of full-fat soya flour into ogi and has given the name 
Soy-Ogi to the final product. It has been estimated (Akinrele, Adeyinka, Edwards, Olatunji, Dina $\&$ Koleoso, I970) that Soy-Ogi could be produced at one-third the cost of the branded infant foods commercially available in Nigeria. Its palatability has been tested extensively amongst children and their parents in urban as well as rural areas. In a report prepared by Cadbury's (Nigeria) Ltd (1969, private communication), based on 600 consumer tests, it was stated that 'except for its unattractive container, the baby food powder (Soy-Ogi) was preferred to the other products compared, a commercial dried cow's milk (Lactogen), a filled milk preparation (SMA) and plain ogi in all other qualities'.

The aim of the investigation now described was to establish the efficacy of Soy-Ogi in preventing and curing protein malnutrition in Nigerian children.

\section{EXPERIMENTAL}

\section{Chemical analyses}

The nutrient composition of Soy-Ogi was determined by standard chemical methods of food analysis. Moisture, ash, ether extractives, protein, fibre, linoleic acid, vitamins $\mathrm{C}, \mathrm{A}$, riboflavin and thiamin were determined by the methods of the Association of Official Agricultural Chemists (1965). Calcium and phosphorus were determined by the Wisconsin Alumni Research Foundation by the method of Christensen, Beckman \& Birdsall (1968). The amino acid profile of Soy-Ogi protein after hydrolysis with boiling $\mathrm{HCl}$ was obtained by single-column chromatography with the Technicon system. Tryptophan was determined by the method of Miller (1967), cystine by performic oxidation (Moore, 1963 ) and available lysine according to Carpenter (1960).

\section{Biological evaluation}

The protein qualities of Soy-Ogi, lactogen and casein were assessed biologically in rats. The following values were determined:

(I) Nitrogen digestibility coefficient $=\frac{[\text { food } N-(\text { faecal } N-\text { metabolic } N)] \times \text { Ioo }}{\text { food } N}$;

$$
\text { [food } \mathrm{N}-(\text { faecal } \mathrm{N}-\text { metabolic } \mathrm{N})
$$

(2) Biological value $=\frac{-(\text { urinary } \mathrm{N}-\text { endogenous } \mathrm{N})] \times 100}{\text { food } \mathrm{N}-(\text { faecal } \mathrm{N}-\text { metabolic } \mathrm{N})}$

(Mitchell, 1924);

(3) Protein efficiency ratio (PER) $=\mathrm{g}$ weight gain $/ g$ protein intake (Osborne, Mendel \& Ferry, 1919);

(4) Corrected PER $=\frac{2 \cdot 5}{\text { experimental PER of casein }} \times$ experimental PER of test diet;

(5) Net protein utilization (NPU) $=\frac{\text { biological value } \times \text { digestibility coefficient }}{100}$

(Platt, Miller \& Payne, I96r). 
(6) Corrected NPU $=\frac{72}{\text { experimental NPU of casein }} \times$ experimental NPU of test diet;

(7) Net dietary protein calories $\%=\mathrm{Pcal} \% \times \mathrm{NPU}$ (operative)

$$
\begin{aligned}
& \text { ( } \mathrm{NDpCal} \% \text { ) } \\
& \text { (Pellett, Kantarjian \& Jamalian, r969) } \\
& \text { where } \mathrm{Pcal} \%=\frac{\mathrm{P} \times 4 \times 100}{\mathrm{ME}} \text {; } \\
& \mathrm{ME}=0.95 \mathrm{GE}-0.075 \times \% \mathrm{~N} \text { (Miller \& Payne, 1959), } \\
& \mathrm{P}=\text { percentage protein in the diet, ME is the metabolizable energy and GE the } \\
& \text { gross energy ( } \mathrm{kcal} / \mathrm{I} 00 \mathrm{~g}) \text {. }
\end{aligned}
$$

Twenty male weanling albino rats, of weights ranging from 70 to $108 \mathrm{~g}$, were allotted

\begin{tabular}{|c|c|c|c|c|c|}
\hline Ingredient & $\begin{array}{c}\text { A } \\
\text { Casein } \\
\text { diet }\end{array}$ & $\begin{array}{c}\text { B } \\
\text { Soy-Ogi } \\
\text { diet }\end{array}$ & $\begin{array}{c}\text { C } \\
\text { Lactogen } \\
\text { diet }\end{array}$ & $\begin{array}{c}\text { D } \\
\text { Soy-Ogi } \\
\text { alone }\end{array}$ & $\begin{array}{c}\mathrm{E} \\
\begin{array}{c}\text { Low-protein } \\
\text { diet }\end{array}\end{array}$ \\
\hline Cassava starch & 702 & 352 & $35^{2}$ & - & 792 \\
\hline Cellulose & 40 & 40 & 40 & - & 40 \\
\hline Maize oil & I 18 & 88 & - & - & II8 \\
\hline Salt mixture* & 20 & 20 & 20 & - & 20 \\
\hline $\begin{array}{l}\text { Yeast and other } \\
\text { vitamin supplements } \dagger\end{array}$ & 20 & 20 & 20 & 20 & 20 \\
\hline \multicolumn{6}{|l|}{ Protein source: } \\
\hline Whole-egg powder & - & - & - & - & ro \\
\hline Casein & 100 & 一 & - & - & - \\
\hline Lactogen & 一 & - & 568 & - & - \\
\hline Soy-Ogi & - & 480 & - & 980 & - \\
\hline Protein content $(\%)$ & I0 & Io & ro & 20 & 2 \\
\hline
\end{tabular}
to four groups according to a randomized block design. Each rat was caged in wire screen mesh, fitted with a container to receive the faeces and urine separately. The faeces and urine were collected in $\mathrm{I} \%(\mathrm{w} / \mathrm{v})$ sulphuric and acetic acids respectively to prevent loss of $\mathrm{N}$. The compositions of the experimental diets are given in Table $\mathrm{I}$.

Table I. Composition ( $g$ ) of experimental diets $A-E$

* Hubbell, Mendel \& Wakeman salt mixture (Hawk, Oser \& Summerson, 1954 b).

$\uparrow$ ENGEVITA Vitamin Dried Yeast (inactive) prepared by Koninklijke Nederlandsche Gist $-\&$ Spiritus fabriek NV, Delft - Holland. $20 \mathrm{~g}$ mixed with 15 drops of Citradex manufactured by Glaxo (Nig) Ltd to provide the vitamins required to meet the needs of a growing rat according to the National Research Council (1962).

Diets $\mathrm{A}, \mathrm{B}$ and $\mathrm{C}$ each contained 10\% crude protein; diet D was left at $20 \%$ protein to determine the net operative protein utilization of Soy-Ogi; the egg-protein diet $\mathrm{E}$ contained $2 \%$ protein. A weighed quantity of each experimental diet was made into a paste with water and put in a wide-mouthed glass bottle fixed to the side of the cage. The food was changed daily and the quantities consumed were carefully weighed. The rats given the low-protein diet $\mathrm{E}$ were allowed $3 \mathrm{~d}$ for adjustment to their cages and were then continued on the diet for $2 \mathrm{r} d$ for the determination of endogenous values. For the determination of the digestibility coefficients and biological values, diets A, B, C and D were given to the rats for $24 \mathrm{~d}$. The faeces and urine excreted by each rat from the $4^{\text {th }}$ to the IIth day of the experimental period were separately 
pooled for $\mathrm{N}$ analysis by the Kjeldahl method (Association of Official Agricultural Chemists, 1965). To obtain PER, the weight gain of each rat on diets $A, B$ and $C$ and the food consumed between the $4^{\text {th }}$ and the 24th days of feeding were measured. Diet D was used to estimate NPU (operative).

At the end of the experimental feeding period, the rats given diets $A, B$ and $C$ were killed and their livers were removed and sectioned for histological examination. The rats on diet D, consisting only of Soy-Ogi fortified with vitamins, were kept on the diet for $150 \mathrm{~d}$. After roo d, two of them were mated with females that had been fed on diet $D$ for the same period. The progeny of the mated rats were reared on Soy-Ogi for $3^{1}$ days after weaning.

\section{Therapeutic evaluation of Soy-Ogi in kwashiorkor}

In collaboration with Lagos University Teaching Hospital, the paediatrician in charge of the Institute of Child Health selected, from among those attending the Nutrition Clinic, fifteen children ( $\mathrm{I}-3$ years old) who were suffering from kwashiorkor at various stages and admitted them to the paediatric wards of the hospital. Each child was examined within $24 \mathrm{~h}$ of admission and the results were recorded on special forms. The diagnosis was graded as severe, moderate, or slight kwashiorkor according to a prearranged system.

The children were weighed naked on admission and every other day thereafter. Blood samples were taken from every patient every $7 \mathrm{~d}$ for $28 \mathrm{~d}$, and analysed for total serum protein, albumin, globulin, packed cell volume (PCV) and haemoglobin by standard clinical methods (Hawk, Oser \& Summerson, 1954a). The children were given antibiotics by injection for the first $5 \mathrm{~d}$ from admission, and prophylactic anti-malarial drugs were regularly administered throughout the period in hospital. Some of the children showed clear signs of vitamin deficiencies such as angular stomatitis. A daily supplement of vitamins and iron was therefore given. The skin lesions due to kwashiorkor were left open and treated with gentian violet. Anorexia was usually overcome by gentle persuasion and persistence; very ill patients were tube-fed.

The diets used in these trials consisted of Soy-Ogi for the test group and a standard commercial infant food, Lactogen, made from dried cow's milk, for the control group. The compositions of the diets are shown in Table 2. Since Soy-Ogi has a higher protein content than Lactogen, glucose was added to the former and the diets were then mixed with water so that each provided equal quantities of protein and calories.

\section{RESULTS AND DISCUSSION}

The nutrient composition of Soy-Ogi is compared with those of a number of branded infant foods in Table 2. Some amino acid profiles are shown in Table 3 . Mean values for the biological evaluation of the protein quality of Soy-Ogi, Lactogen and casein diets are given in Table 4.

Except for deficiencies in vitamins and in iron, which can be corrected by fortification, Soy-Ogi presents a nutrient profile and protein score which compare favourably 
with those of branded commercial infant foods. About $70 \%$ of its lysine content is available, indicating a good biological value.

Its NDpCal \% is estimated at 10.80 using the corrected NPU value. This value is well above the minimum of 8 recommended for children, and therefore Soy-Ogi should be

Table 2. Percentage composition of Soy-Ogi as compared with other protein foods

\begin{tabular}{|c|c|c|c|c|c|c|c|c|c|}
\hline Constituent & $\begin{array}{l}\text { Soy-Ogi } \\
\text { (Nigeria) }\end{array}$ & $\begin{array}{l}\text { Pro-Nutro } \\
\text { (South } \\
\text { Africa) }\end{array}$ & $\begin{array}{l}\text { Inca- } \\
\text { parina } \\
\text { (Guate- } \\
\text { mala) }\end{array}$ & $\begin{array}{l}\text { Farlene } \\
\text { (Nestle) }\end{array}$ & $\begin{array}{l}\text { Complan } \\
\text { (Glaxo) }\end{array}$ & $\begin{array}{l}\text { Lactogen } \\
\text { (Nestle) }\end{array}$ & $\begin{array}{l}\text { Corn-soya } \\
\text { meal } \\
\text { (America) }\end{array}$ & $\begin{array}{l}\text { Nestum } \\
\text { (Nestle) }\end{array}$ & $\begin{array}{c}\text { Farex } \\
\text { (Glaxo) }\end{array}$ \\
\hline Protein $(\mathrm{N} \times 6.25)$ & $20 \cdot 3$ & $22 \cdot 0$ & $27 \cdot 5$ & $25^{\circ} 0$ & $3 I \cdot 0$ & $16 \cdot I$ & 20.9 & $14^{\circ} 0$ & $14 \cdot 2$ \\
\hline Moisture & 4.7 & - & - & 4.0 & - & 3.0 & $9 \cdot 5$ & $5 \cdot 0$ & $6 \cdot 5$ \\
\hline Fat & $6 \cdot 3$ & $12 \cdot 9$ & $4 \cdot 2$ & $5 \cdot 5$ & 16.0 & $24 \cdot 2$ & $1 \cdot 2$ & $2 \cdot 0$ & $2 \cdot 5$ \\
\hline Ash & $3 \cdot 0$ & 4.6 & - & $4 \cdot 0$ & - & $3 \cdot 6$ & $2 \cdot 1$ & $3 \cdot 5$ & $2 \cdot 1$ \\
\hline Calcium & 0.43 & 0.46 & 0.66 & 0.78 & 0.83 & 一 & 0.40 & 0.35 & 0.89 \\
\hline Phosphorus & 0.44 & 0.48 & 0.70 & - & 0.78 & - & 0.44 & 0.45 & 0.68 \\
\hline Carbohydrate & $63 \cdot 7$ & $5^{6 \cdot 5}$ & 一 & $60 \cdot 5$ & - & $52 \cdot 4$ & $6 r \cdot 0$ & $75 \cdot 5$ & $72 \cdot 7$ \\
\hline Energy (kcal/g) & 4.00 & $4 \cdot I 3$ & $3 \cdot 70$ & 3.90 & 一 & $4 \cdot 95$ & $3 \cdot 5^{8}$ & 3.66 & 3.57 \\
\hline
\end{tabular}

Table 3. Amino acid pattern (mg/g) of some infant foods

\begin{tabular}{|c|c|c|c|c|}
\hline Amino acid & Soy-Ogi & Lactogen & $\begin{array}{c}\text { Corn-soya } \\
\text { meal } \\
\text { (America) }\end{array}$ & $\begin{array}{c}\text { FAO (x957) } \\
\text { (reference } \\
\text { protein) }\end{array}$ \\
\hline Tryptophan & $2 \cdot 10$ & $2 \cdot 18$ & $2 \cdot 40$ & $2 \cdot 88$ \\
\hline Threonine & $7 \cdot 63$ & $7 \cdot 15$ & - & $5 \cdot 76$ \\
\hline Isoleucine & $8 \cdot 85$ & $9 \cdot 89$ & 一 & $8 \cdot 64$ \\
\hline Leucine & $17 \cdot 69$ & $15 \cdot 21$ & - & $9 \cdot 7^{8}$ \\
\hline Lysine & $9 \cdot 46$ & 12.05 & $9 \cdot 60$ & $8 \cdot 64$ \\
\hline Methionine & $2 \cdot 75$ & 3.79 & 3.61 & \\
\hline Cystine & 3.05 & $1 \cdot 39$ & $2 \cdot 80\}$ & $8 \cdot 64$ \\
\hline Phenylalanine & 10.68 & $7 \cdot 51$ & 一 & $5 \cdot 76$ \\
\hline Valine & $9 \cdot 76$ & 10.64 & - & $8 \cdot 64$ \\
\hline Histidine & $4 \cdot 88$ & 4.08 & - & - \\
\hline Serine & $9 \cdot 76$ & $9 \cdot 14$ & - & - \\
\hline Protein score & 93 & 78 & 89 & 100 \\
\hline
\end{tabular}

Table 4. Comparative biological evaluation of some food proteins

(Mean values for diets containing $10 \%$ protein)

\begin{tabular}{|c|c|c|c|}
\hline Analysis & $\underset{\text { Casein }}{\text { A }}$ & $\begin{array}{c}\text { B } \\
\text { Soy-Ogi }\end{array}$ & $\begin{array}{c}\text { C } \\
\text { Lactogen }\end{array}$ \\
\hline $\begin{array}{l}\text { Protein efficiency ratio: } \\
\text { Experimental* } \\
\text { Corrected (using standard } \\
\text { value for casein) }\end{array}$ & $\begin{array}{l}2 \cdot 6 \pm 0 \cdot 37 \\
2 \cdot 5\end{array}$ & $\begin{array}{l}2 \cdot 3 \pm 0 \cdot 21 \\
2 \cdot 2\end{array}$ & $\begin{array}{l}2 \cdot 2 \pm 0.62 \\
2 \cdot 1\end{array}$ \\
\hline $\begin{array}{l}\text { Net protein utilization: } \\
\text { Experimental }\end{array}$ & $85 \cdot 5$ & $\begin{array}{l}83 \cdot 6 \text { (standard) } \\
69 \cdot 5 \pm 3 \cdot 79 \\
\text { (operative)* }\end{array}$ & $86 \cdot 6$ \\
\hline $\begin{array}{l}\text { Corrected (using standard } \\
\quad \text { value for casein) } \\
\text { Nitrogen digestibility coefficient: }\end{array}$ & $72 \cdot \circ \dagger$ & $\begin{array}{l}70 \cdot 4 \text { (standard) } \\
58 \cdot 5 \text { (operative) }\end{array}$ & $72 \cdot 9$ \\
\hline Experimental* & $96.6 \pm 0.61$ & $91 \cdot 6 \pm 2 \cdot 15$ & $93 \cdot 1 \pm 2 \cdot 59$ \\
\hline $\begin{array}{l}\text { Biological value: } \\
\text { Experimental* }\end{array}$ & $88 \cdot 5 \pm 3 \cdot 63$ & $91 \cdot 3 \pm 2 \cdot 86$ & $93 \cdot 0 \pm 2 \cdot 45$ \\
\hline
\end{tabular}


a suitable food for weaning children. The results of the long-term feeding tests indicated that the livers of rats fed on Soy-Ogi were normal and the successful feeding of the rats solely on Soy-Ogi through a complete life cycle which resulted in normal litter sizes, birth weights and growth rates provided further evidence that potent toxic residues were absent from the food.

In the children, the response to dietary treatment was measured in terms of acceptance and tolerance of the food, disappearance of oedema and apathy, and weight changes. After the first $5 \mathrm{~d}$, the Soy-Ogi diet was found to be as acceptable as the Lactogen diet, but the initial anorexia was more easily overcome with the Lactogen diet. This

Table 5. Response of the children to dietary treatment for $2 \mathrm{I} d$

\begin{tabular}{|c|c|c|c|c|c|c|c|c|c|}
\hline Child & Sex & $\begin{array}{c}\text { Age } \\
\text { (years) }\end{array}$ & Diagnosis & $\begin{array}{l}\text { No. of } \\
\text { vomits }\end{array}$ & $\begin{array}{l}\text { Fre- } \\
\text { quency } \\
\text { of diar- } \\
\text { rhoea } \\
\text { (no. of } \\
\text { times) }\end{array}$ & $\begin{array}{l}\text { Day on } \\
\text { which } \\
\text { oedema } \\
\text { disap- } \\
\text { peared }\end{array}$ & $\begin{array}{l}\text { Day on } \\
\text { which } \\
\text { apathy } \\
\text { disap- } \\
\text { peared }\end{array}$ & $\begin{array}{l}\text { Time to } \\
\text { attain } \\
\text { minimum } \\
\text { weight (d) }\end{array}$ & $\begin{array}{l}\text { Rise in } \\
\text { serum } \\
\text { proteins } \\
(\mathrm{g} / \mathrm{I} 00 \mathrm{ml})\end{array}$ \\
\hline \multicolumn{10}{|c|}{ Soy-Ogi group } \\
\hline A.S. & 우 & 2 & $\begin{array}{l}\text { Moderate } \\
\text { kwashiorkor }\end{array}$ & 0 & o & 7 th & r6th & 7 & $1 \cdot 58$ \\
\hline S. J. & 우 & $2 \cdot 25$ & $\begin{array}{l}\text { Moderate } \\
\text { kwashiorkor }\end{array}$ & 3 & $\circ$ & r5th & 21st & r8 & 0.97 \\
\hline T.Y. & o & $1 \cdot 5$ & $\begin{array}{l}\text { Severe } \\
\text { kwashiorkor }\end{array}$ & I & o & 2oth & 23 rd & $2 \mathrm{I}$ & $I \cdot 64$ \\
\hline Sal. J. & $\hat{0}$ & $2 \cdot 5$ & $\begin{array}{l}\text { Moderate } \\
\text { kwashiorkor }\end{array}$ & 2 & ○ & II th & 2Ist & 9 & $\mathrm{I} \cdot 38$ \\
\hline Ay.S. & $\sigma$ & $1 \cdot 5$ & $\begin{array}{l}\text { Severe } \\
\text { kwashiorkor }\end{array}$ & $\mathbf{I}$ & ○ & I $3^{\text {th }}$ & 2oth & I3 & $r \cdot 88$ \\
\hline \multicolumn{10}{|c|}{ Lactogen group } \\
\hline O.F. & $0^{*}$ & $r \cdot 5$ & $\begin{array}{l}\text { Severe } \\
\text { kwashiorkor }\end{array}$ & 4 & 0 & i th & 21 st & 7 & $2 \cdot 35$ \\
\hline S.O. & $\delta$ & 2 & $\begin{array}{l}\text { Severe } \\
\text { kwashiorkor }\end{array}$ & o & I & IIth & 2oth & II & 3.44 \\
\hline 0.0 . & q & $\mathrm{I} \cdot 5$ & $\begin{array}{l}\text { Moderate } \\
\text { kwashiorkor }\end{array}$ & o & 7 & 6th & 2oth & 2 & I.99 \\
\hline
\end{tabular}

may have been mainly because the Lactogen diet for the first $3 \mathrm{~d}$ was a thin fluid without pap. The Soy-Ogi diet, no matter how thinly it was prepared, always set into a thin gel on standing. Such semi-solids are less readily taken than fluids by sick children. Vomiting was a common problem with both diets, especially during the first few days of treatment. Not all the vomiting could be attributed to dietary intolerance (Table 5). The temperature and manner in which the food was administered seemed to affect tolerance. When the food was given cold and in a hurried manner the patient was more prone to vomiting.

Diarrhoea occurred only in the Lactogen group, probably because many Nigerian children seem to be intolerant of lactose.

Oedema in the Soy-Ogi group subsided in one patient at the end of the Ist week, and in the others between the 2 nd and 3 rd weeks. In the Lactogen group oedema disappeared in one child in the Ist week and in the two others in the 2nd and $3^{\text {rd }}$ weeks. 
Disappearance of apathy and increasing interest in the environment became noticeable in all children in both groups in the $3^{\text {rd }}$ week. This means that clinically the patients fed on Soy-Ogi showed as good a response as those fed on Lactogen.

The curves of changes in weight, total serum proteins and albumin concentrations over a period of $28 \mathrm{~d}$ treatment, derived from two typical patients from both groups, are shown in Fig. I. It will be seen that there was greater weight loss in the patients on Soy-Ogi than in those on Lactogen. After the initial loss in weight, the Lactogen group gained more weight and at a faster rate than the Soy-Ogi group, which is in

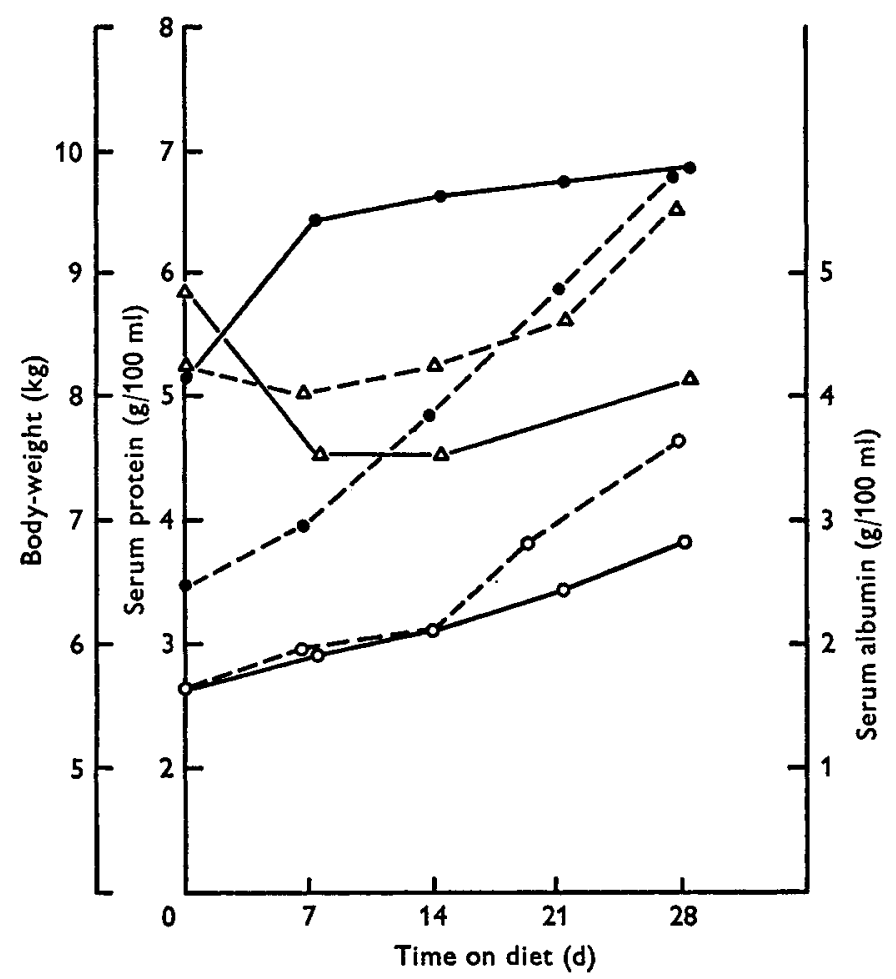

Fig. I. Recovery patterns of kwashiorkor patients during dietary therapy. -0 , total serum protein (Soy-Ogi); $O-O$, serum albumin (Soy-Ogi); $\triangle-\triangle$, body-weight (Soy-Ogi); -. 0 , total serum protein (Lactogen); $0-\cdots 0$, serum albumin (Lactogen); $\triangle-\cdots \Delta$, body-weight (Lactogen).

agreement with the observations of Dean (1952). Increases in total serum protein concentration were also greater in the children fed on Lactogen than in those on Soy-Ogi, as was also found by Arroyave, Wilson, Béhar \& Viteri (196r). At the end of a month's treatment two of the patients on Soy-Ogi still had serum protein levels below normal. Serum albumin concentration rose steadily in all the children, but the rate of increase was higher in the patients on Lactogen than in those on Soy-Ogi.

By the 2ist day of treatment serum albumin concentrations had returned to the normal level of about $3 \mathrm{~g} / 100 \mathrm{ml}$ in the Lactogen group. This indicates that Lactogen may be more efficient in promoting serum protein recovery than Soy-Ogi, although the values obtained with the latter diet were acceptable. 
Only eight children out of fifteen successfully completed $28 \mathrm{~d}$ of the prescribed treatment. Four patients (two in each group) died during the period of treatment, and three others were discharged because of early recovery.

\section{Conclusion}

This study has suggested that Soy-Ogi is a complete protein food suitable for weaning children. It has also been established that it is acceptable, free from toxic residues, and could be well tolerated by children. The limited trials on children also suggest that it has the advantage of minimizing the frequency of diarrhoea often observed with a milk diet. However, when compared with Lactogen, it is less efficient for the treatment of kwashiorkor in bringing about maximum weight gains and rapid increase in the serum albumin concentration.

Table 6. Relative cost of Soy-Ogi and other infant foods

\begin{tabular}{|c|c|c|c|}
\hline Infant food & $\begin{array}{c}\text { New pence/ } \\
\mathrm{kg}\end{array}$ & $\begin{array}{c}\text { Protein content } \\
(\%)\end{array}$ & $\begin{array}{l}\text { New pence/ } \\
20 \mathrm{~g} \text { protein }\end{array}$ \\
\hline Soy-Ogi* (Nigeria) & 30 & $20 \cdot 4$ & $3 \cdot 0$ \\
\hline Incaparina" (Guatemala) & $2 \mathrm{I}$ & 27.5 & I.6 \\
\hline Pro-Nutro* (S. Africa) & $2 \mathrm{I}$ & $22 \cdot 0$ & $2 \cdot 0$ \\
\hline Incaparina (Mexico) & ro & 27.5 & 0.8 \\
\hline Nestum (Cereal) & 79 & 14.0 & $\mathrm{II} \cdot 4$ \\
\hline Farex (Cereal) & 79 & $14 \cdot 2$ & II:2 \\
\hline Lactogen (Milk) & 54 & 16.9 & 6.4 \\
\hline Complan (Milk) & 138 & $31 \cdot 0$ & $9 \cdot 0$ \\
\hline Humanized Trufood (Milk) & 62 & $\times 4.50$ & $8 \cdot 6$ \\
\hline Farlene (Cereal) & 123 & 25.00 & $9 \cdot 8$ \\
\hline
\end{tabular}

Because of the relatively low cost of Soy-Ogi in comparison with other weaning foods (Table 6), and the limited purchasing power of the low-income group, SoyOgi should be considered as the food of choice for the prevention and cure of mild and moderate protein malnutrition. In severe kwashiorkor which may require hospital treatment, Soy-Ogi supplemented with a milk diet is preferable.

The authors are grateful to the US Department of Health, Education and Welfare, Bethesda, Maryland, who arranged for the vitamin and elemental analyses of SoyOgi by the Wisconsin Alumni Research Foundation, and to the Tropical Products Institute, London for the amino acid analyses. We also wish to acknowledge the support given to us through clinical management of the hospital patients by the staff of the Institutes of Child Health and the Paediatric Department of the Lagos University Teaching Hospital.

\section{REFERENCES}

Akinrele, I. A. (rg66). A biochemical study of the traditional method of preparation of Ogi and its effects on the nutritive value of corn. PhD Thesis, University of Ibadan.

Akinrele, I. A., Adeyinka, O., Edwards, C. C. A., Olatunji, F. O., Dina, J. A. \& Koleoso, O. A. (1970). The Development and Production of Soy-Ogi. F.I.I.R. Research Report no. 42. Lagos, Nigeria: Federal Ministry of Industries. 
Arroyave, G., Wilson, D., Béhar, M. \& Viteri, F. (196I). Publs natn. Res. Coun., Wash. no. 843.

Association of Official Agricultural Chemists (1965). Official Methods of Analysis roth ed. Washington, D.C.: Association of Official Agricultural Chemists.

Brock, J. F. (I96I). Proc. int. Congr. Nutr. v. Washington Vol. 20, p. 6r.

Carpenter, K. J. (r960). Biochem. F. 77, 604 .

Christensen, R. E., Beckman, R. M. \& Birdsall, J. J. (1968). 7. Ass. off. agric. Chem. 51, 1003.

Collis, W. R. F., Dema, J. \& Omololu, A. (1962). Trop. geogr. Med. 14, 140.

Dean, R. F. A. (1952). Br. med. F. ii, 791.

FAO (1957). F.A.O. nutr. Stud. no. I6.

Hawk, P. B., Oser, B. L. \& Summerson, W. H. (1954a). Practical Physiological Chemistry 13th ed., p. 602. London: J. and A. Churchill.

Hawk, P. B., Oser, B. L. \& Summerson, W. H. (1954b). Practical Physiological Chemistry 13th ed., p. 1375. London: J. and A. Churchill.

Miller, D. S. \& Payne, P. R. (1959). Br. F. Nutr. 13, 50r.

Miller, E. L. (1967). F. Sci. Fd Agric. 18, 381 .

Mitchell, H. H. (1924). F. biol. Chem. 58, 873 .

Moore, S. (1963). F. biol. Chem. 238, 235.

Morley, C. D. (1958). W. Afr. med. F. 7, 34.

National Research Council (r962). Publs natn. Res. Coun., Wash. no. 990.

Osborne, T. B., Mendel, L. B. \& Ferry, E. L. (1919). F. biol. Chem. 37, 223.

Pellett, P. L., Kantarjian A. \& Jamalian, J. (1969). F. Sci. Fd Agric. 20, 229.

Platt, B. S., Miller, D. S. \& Payne, P. R. (196r). In Recent Advances in Human Nutrition p. 35I [J. F. Brock, editor]. London: Churchill.

Williams, C. D. (1933). Archs Dis. Childh. 8, 423.

WHO (1965). Tech. Rep. Ser. Wld Hlth Org. no. 301. 